**The Version of Record of this manuscript has been published and is available in the European Journal of Work and Organizational Psychology, 12 May 2020

https://www.tandfonline.com/doi/full/10.1080/1359432X.2020.1761445**

THE INTERACTING CONTENT AND PROCESS OF THE EMPLOYER BRAND: PERSON-ORGANIZATION FIT AND EMPLOYER BRAND CLARITY

Keywords: Employer branding, employer attractiveness, HRM system strength theory, person-organization fit, clarity, multilevel

Sanne Theodora Sophia Ghielen

KU Leuven, Belgium

Rein De Cooman

KU Leuven, Belgium

Luc Sels

KU Leuven, Belgium 
PO FIT AND EMPLOYER BRAND CLARITY

Funding. This research was funded by Randstad Belgium through the Randstad Chair on 'Employer Brand Equity’ that was awarded to KU Leuven.

Earlier versions. An earlier draft of this paper was presented at the $78^{\text {th }}$ Annual Meeting of the Academy of Management in Chicago, Illinois. This paper was also designated among the (approximately 10\%) best papers of the HR division of the $78^{\text {th }}$ Annual Meeting of the Academy of Management in Chicago, Illinois. Therefore, an abridged version of the paper has been included in the Academy of Management Proceedings (doi:10.5465/AMBPP.2018.255).

Acknowledgements. We would like to thank Greet Van Hoye (Professor, Ghent University) and Sophie De Winne (Professor, KU Leuven) for their friendly review of an earlier draft of this paper.

Corresponding author. Ms. Sanne T.S. Ghielen, Naamsestraat 69, box 3545, 3000 Leuven, Belgium.e-mail: sanne.ghielen@kuleuven.be

Data availability statement. Data subject to third party restrictions: The data that support the findings of this study are available from Randstad Belgium. Restrictions apply to the availability of these data, which were used under license for this study. Data are available from the corresponding author with the permission of Randstad Belgium. 
PO FIT AND EMPLOYER BRAND CLARITY

\title{
THE INTERACTING CONTENT AND PROCESS OF THE EMPLOYER BRAND: PERSON-ORGANIZATION FIT AND EMPLOYER BRAND CLARITY
}

\begin{abstract}
In their striving to be an attractive employer, organizations aspire to create effective employer brands. Building on HRM system strength theory, we posit that the effectiveness of an employer brand is determined by the integration of its content and process. This paper investigates whether person-organization fit (i.e. employer brand content) is positively linked to employer attractiveness and whether employer brand clarity (i.e. process) strengthens this relationship. Using a secondary dataset containing 24317 responses from 2123 individuals reporting on 235 Belgian organizations, a cross-classified multilevel model was tested. Findings reveal that person-organization fit relates to employer attractiveness above and beyond universally appealing features of the employer (e.g. career progression opportunities). Unexpectedly, a negative moderation effect of employer brand clarity was found, indicating that clarity might be useful in case of low person-organization fit, but is not when personorganization fit is optimal. Replication studies yielded similar results, which confirms our findings and highlights the relevance of both the employer brand content and the employer branding process as determinants of employer attractiveness.
\end{abstract}


PO FIT AND EMPLOYER BRAND CLARITY

\section{INTRODUCTION}

Shortages on the labor market are a growing concern for organizations in (among other economies) European economies (Collins \& Kanar, 2014). The proportion of the European workforce aged 55 to 64 years will increase from between 10 and 18 percent in 2014 to 12 and 27 percent in 2035 (reflecting the minimum and maximum percentages for European countries, Aiyar, Ebeke \& Shao, 2016). Simultaneously, Europe will continuously face low fertility and mortality rates (Eurostat, 2019). Together with prosperous economies, these circumstances cause a highly competitive labor market in which attracting the best possible workforce is among the most important sources of competitive advantage for organizations. Recruitment has therefore become a vital human resource (HR) practice for organizations to outperform their competitors in the so-called 'war for talent' (Taylor \& Collins, 2000; Phillips \& Gully, 2015; Volopne, Thomas, Sinisterra, \& Johnson, 2014).

In order to win this war for talent, recruitment increasingly focuses on providing prospective employees with information about an employer's value proposition and reputation (Murphy \& Tam, 2004). This strategy of employer branding generates a constant (recruitment) message that captures information about the organization as an employer, as opposed to information about the general corporate brand and specific job features (Chapman \& Mayers, 2015; Collins \& Kanar, 2014). The promoted employer brand comprises unique and desirable aspects of the organization as an employer as it highlights the organization's functional, economic, and psychological benefits (Ambler \& Barrow, 1996).

Prior research in employer branding primarily focused on the content of the employer brand by identifying potential employer brand elements (e.g. competitive salaries/benefits and career progression opportunities (Biswas \& Suar, 2016; Lievens \& Highhouse, 2003; Tumasjan, Kunze, Bruch \& Welpe, 2020). The vast majority of these studies merely tests 


\section{PO FIT AND EMPLOYER BRAND CLARITY}

whether an employer brand that comprises numerous universally desired employer brand elements is a strong employer brand and therefore maximizes employer attractiveness (e.g. Lievens, Van Hoye \& Anseel, 2007). However, the focus on the effects of an extensive, universally desired employer brand content overlooks the importance of individual employer brand preferences, whilst prior research acknowledged that individuals' employer brand preferences are not alike (Lievens \& Slaughter, 2016). Moreover, the strength of an employer brand may not only depend on the content of the employer brand (i.e. employer brand elements), but also on the process of how the employer brand is promoted (e.g. whether or not the organization communicates clearly and unambiguously about its employer brand content, Bowen \& Ostroff, 2004).

Hence, employer branding research so far does not incorporate two relevant matters: (1) the importance of diverse individual preferences with regard to the employer brand content, and (2) how the employer branding process may facilitate the transmission of the employer brand content. The objective of this study is thus to refine employer branding research by incorporating these issues. In particular, we draw on HRM system strength theory (Bowen \& Ostroff, 2004) to outline the importance of the abovementioned matters within the context of employer branding. Combining this theory with person-environment fit theory and signaling theory (Spence, 1973) allows to systematically examine the influence personorganization (PO) fit based on employer brand attributes (i.e. content) on employer attractiveness and the moderation effect of employer brand clarity (i.e. process). To produce an enriched understanding of the link between the employer brand content, process, and employer attractiveness, we test the proposed relationships in a cross-classified multilevel model including 24317 responses from 2123 individuals reporting on 235 Belgian organizations. Moreover, we attempt to (partially) address the often made claims of a replication crisis (e.g. Shrout \& Rodgers, 2018; Singh, Ang \& Leong, 2003), as we aspire to 


\section{PO FIT AND EMPLOYER BRAND CLARITY}

confirm our findings by conducting two true replication studies using largely similar secondary data. Altogether, this research holds promise to theoretically advance our knowledge about effective employer brands by looking at the interaction between content and process, and further the empirical measurement of the employer brand content through the use of PO fit, which incorporates individual differences with regard to preferences for certain employer brand elements.

\section{THEORETICAL FRAMEWORK}

In the literature, employer branding has been approached from a marketing as well as a human resource management perspective which engendered various definitions of the concept. Backhaus and Tikoo (2004) define employer branding as the process of building an identifiable and unique employer identity that promotes the unique and attractive image of an employer. The definition of Lievens (2007) accentuates that employer branding involves the promotion of a clear view of what makes the organization different and desirable as an employer to internal and external audiences, whereas Edwards (2009, p6) emphasizes the branding aspect by defining employer branding as 'the science of branding applied to HR activities in relation to current and potential employees'. These definitions reveal three important elements of employer branding. First, employer branding is a process that aims to promote the employer as a desirable and attractive employer to current and prospective employees. Second, the promotion occurs through applying branding strategies that enhance a clear view of the organization as an employer. Third, the brand that is promoted should be unique and thereby highlight the employer features that distinguishes the organization from its competitors. Employer branding can thus be defined as the process of promoting a clear view of an organization as a unique and attractive employer to current and potential employees. 


\section{PO FIT AND EMPLOYER BRAND CLARITY}

The content (i.e. employer features) that is branded is described by the term employer brand, which was first introduced by Ambler and Barrow in the mid-90s as 'the package of functional, economic, and psychological benefits provided by employment, and identified with the employing company' (Ambler \& Barrow, 1996, p187). Functional benefits refer to developmental and/or useful activities, economic benefits reflect material or monetary rewards and psychological benefits include feelings such as belonging, direction and purpose. More recent studies deviate from these three categories by defining the employer brand as 'a package of instrumental and symbolic attributes' (Lievens et al., 2007). This definition refers to the instrumental-symbolic framework that has gained a central position in the employer brand(ing) literature ever since its application was introduced by Lievens and Highhouse in 2003. The instrumental attributes involve objective job or organizational characteristics such as salary, growth opportunities, and flexible working arrangements, whereas symbolic attributes refer to intangible, subjective organizational characteristics such as prestige or competence. In light of the original definition of Ambler and Barrow (1996), instrumental elements would reflect functional and economic benefits whereas symbolic elements would cover the psychological benefits.

Multiple studies tested the instrumental-symbolic framework and revealed that both instrumental functions and symbolic meanings explain incremental variance in predicting employer attractiveness (e.g. Lievens et al., 2007; Van Hoye, Bas, Cromheecke, \& Lievens, 2013). Independent of the instrumental-symbolic framework, other studies also investigated specific components of an employer brand as antecedents of employer attractiveness. It has for example been found that equity in reward administration, strong leadership of top management and valued products and services positively influence employer attractiveness (Biswas \& Suar, 2016). These elements however, also fit into the instrumental-symbolic framework since equity in reward administration and leadership of top management reflect 


\section{PO FIT AND EMPLOYER BRAND CLARITY}

instrumental elements and valued products and services may be captured in the symbolic attribute prestige. All employer brand elements that conform to the instrumental-symbolic framework could be part of the employer brand content. Whilst previous research primarily builds on the premise 'the more elements, the better' indicating that promoting numerous universally desired elements maximizes employer attractiveness, this study in addition emphasizes the relevance of a focused employer brand content targeting individual preferences, and the process of employer branding. To this extent, we propose that an effective employer brand constitutes a unique brand that incorporates the individual preferences of the targeted workforce, is clearly promoted to internal and external audiences and strives for an optimal integration between the employer brand content and the process of employer branding.

\section{Employer brand content: a person-environment fit perspective}

According to person-environment fit theory, individuals search for environments that are congruent with their personal characteristics (e.g. values, abilities, needs). They react positively to this congruity, because in fitting environments activities and relationships fulfill individuals' needs, call upon their abilities, and reinforce them as an individual by confirming their values (Kristof-Brown \& Guay, 2011).

PO fit is among the most studied types of fit and often conceptualized as value congruence between individuals and organizations (Kristof, 1996). Indeed, two meta-analyses confirmed that PO fit (defined as value congruence) is related to organizational attraction during all stages of the recruitment process (Chapman, Uggerslev, Caroll, Piasentin \& Jones, 2005; Uggerslev, Fassina \& Kraichy, 2012). Even beyond factors such as the quality of the recruitment process, job and organizational elements, value congruence remained a significant predictor of organization attraction and job choice intentions (Cable \& Judge, 1996; 


\section{PO FIT AND EMPLOYER BRAND CLARITY}

Uggerslev et al., 2012). This particular operationalization of PO fit has thus been repeatedly linked to organizational attraction, and accounts for individual differences with regard to organizational attraction during the recruitment process.

In addition to organizational values, PO fit can also be operationalized as congruity between what an individual demands and what an organization supplies in employment agreements (i.e., needs-supply fit, Kristof, 1996). Such needs-supply approach has often been studied in the context of specific jobs (i.e. person-job fit, Kristof-Brown \& Guay, 2011), and found to be an antecedent of employer attractiveness (Carless, 2005). However, such needssupply approach gained little attention in relation to PO fit, in which it would refer to general supplies of the organization opposed to job-specific supplies (Kristof, 1996). We believe that individual differences in employer attractiveness may be adequately predicted by a fit measure that reflects the compatibility between an individual's employer brand preferences and an organization's employer brand that can both refer to value congruence (i.e. symbolic elements) and needs-supply fit (i.e. instrumental elements). Since the impact of PO fit based on value congruence on employer attractiveness is thoroughly studied, this study addresses fit between individuals' needs and organizations' supplies in terms of instrumental employer brand elements.

In detail, PO fit in this study reflects a calculated subjective type of fit since it captures the congruence between the individual's top five of instrumental employer brand elements (e.g. career progression opportunities, long term job security) and the perceived employer brand elements an organization provides (see e.g. Kristof-Brown \& Billsberry, 2013; KristofBrown \& Guay, 2011). Overall, PO fit taking a needs-supply perspective complements prior research and could be a valid way of incorporating individual differences in the measurement of employer brand content. Therefore, we hypothesize the following: 
PO FIT AND EMPLOYER BRAND CLARITY

Hypothesis 1: Person-organization fit positively relates to employer attractiveness.

\section{Employer brand process: brand clarity}

Albeit the content of the employer brand is highly important for its effectiveness, HRM system strength theory emphasizes the relevance of the process (i.e. employer branding strategies, Bowen \& Ostroff, 2004). According to HRM system strength theory, process refers to 'how the HRM system can be designed and administered effectively by defining metafeatures of an overall HRM system that can create strong situations in the form of shared meaning about the content that might ultimately lead to organizational performance' (Bowen \& Ostroff, 2004, p206). This notion is strongly related to the branding literature, in which 'getting the message across' is the central premise.

Sending signals is fundamental to both the branding and HRM literature as well as in the employer branding literature. Employer branding functions as a signal that diminishes information asymmetry, which is explained by signaling theory (Spence, 1973). Signaling theory initially addressed the uncertainty of employers about the capabilities of individuals at the moment of hiring and argued that high-quality prospective employees attempt to distinguish themselves through signaling their higher education (Celani \& Singh, 2011; Connelly, Certo, Ireland \& Reutzel, 2011). In the recruitment context, signaling theory has, however, been applied from an applicant's perspective. Applicants construct impressions of organizations based on signals conveyed to them during the recruitment process (e.g. Collins \& Stevens, 2002; Rynes, Bretz \& Gerhart, 1991). Given the fact that the uncertainty throughout the recruitment process poses a risk for the organization as well as prospective employees, it is in both interests that an organization clearly signals its employer features to the employment market (Breaugh \& Starke, 2000; Wilden, Gudergan \& Lings, 2010). 


\section{PO FIT AND EMPLOYER BRAND CLARITY}

The clarity of an employer brand signal is potentially a crucial element of the employer branding process, given the recurrent emphasis on clarity throughout employer branding research. For instance, Lievens' (2007) definition of employer branding states that 'employer branding [...] involves the promotion of a clear view [...]' (emphasis added, p51). Moreover, Wilden and colleagues (2010) affirm the importance of employer brand clarity building on the branding literature in which clarity is defined as the absence of ambiguous information conveyed by past and present branding activities (Erdem \& Swait, 1998; Wilden et al., 2010). The relevance of sending unambiguous signals is also highlighted by HRM system strength theory (Bowen \& Ostroff, 2004), which proposes that strong HRM systems send unambiguous signals that enhance clarity of interpretation and thereby fosters similar individual perceptions of the meaning of the HRM system. Considering the above, we argue that employer brand clarity, which can be determined by low ambiguity regarding the employer branding content that results in little variability among individual's interpretations, is a key component of the employer branding process and thereby is essential for an effective employer brand.

\section{The interacting content and process}

The HRM system strength theory states that strong and unambiguous HRM systems are thought to benefit an organization's performance through the interaction of both content and process (Bowen \& Ostroff, 2004). In the context of employer branding, this would imply that an adequate integration between the content of the employer brand (i.e. PO fit) and the process of employer branding (i.e. clarity) will maximize employer attractiveness as the process of employer branding will allow to understand the intended employer brand content (Bowen \& Ostroff, 2004). These ideas are in accordance with signaling theory, which highlights that content wise an employer brand can serve as a signal, but that the application 


\section{PO FIT AND EMPLOYER BRAND CLARITY}

of branding strategies is needed to ensure that the signal is adequately conveyed to potential employees (Wilden et al., 2010).

Thus, we posit that employer brand clarity may foster the transmission of the employer brand content. Following Wilden and colleagues (2010), we argue that employer brand clarity decreases information costs, because a clear image of the organization as an employer reduces the effort prospective employees have to make into unpacking and interpreting the employer brand message (i.e. content). Lower information costs foster similar perceptions of the employer brand, which helps to get the right message across (Bowen \& Ostroff, 2004). Moreover, the smooth unpacking of the employer brand content leads to lower perceived risks associated with being employed for the organization since the individual will be more secure about the employer brand content. Ultimately, this intensifies the expected utility of working for the particular employer (as the employer brand content reveals) and the associated employer attractiveness (Wilden et al., 2010). In this study, PO fit reflects the content of the employer brand, which implies that employer brand clarity allows individuals to make veridical comparisons between their personal employer brand preferences and the organization's supplies (Tumasjan et al., 2020). In case of low levels of PO fit, high levels of employer brand clarity may function as a confirmation of the absence of PO fit and induce the lowest level of employer attractiveness. Similarly, high levels of employer brand clarity may confirm the existence of high PO fit and thereby induce the highest level of employer attractiveness. In contrast, low levels of employer brand clarity are assumed to neither strengthen nor weaken the relationship between PO fit and employer attractiveness. Building on the aforementioned, we hypothesize that: 
PO FIT AND EMPLOYER BRAND CLARITY

Hypothesis 2: Employer brand clarity positively moderates the relationship between PO fit and employer attractiveness, such that the effects of $P O$ fit on employer attractiveness are more pronounced when employer brand clarity is high.

\section{METHOD}

\section{Research design}

Randstad, a global organization in the HR services industry, annually collects data about the employer brands of multiple organizations through their Randstad Employer Brand Research. The survey is distributed online to a representative sample (except from students who were overrepresented given their importance for employers) of the Belgian population of which contact information is derived through the company's database. The survey comprises two parts. The first part contains, besides personal information, a top 5 ranking on personal preferences of 18 employer brand elements. The second part concerns questions regarding organizations operating in Belgium that were included because they either had over 1000 employees or were separately selected by Randstad to provide additional insights in their employer brand (e.g. because they operated in the non-profit sector or are seen as impactful Belgian companies). To each individual, a random sample of 30 organizations was presented for which they had to select each organization they were familiar with. For those organizations they were familiar with, the respondents indicated to what extent they would like to work for the organization and subsequently indicated whether 10 employer brand elements applied to the particular organization on a 5-point Likert scale ranging from 'not true at all' to 'completely true'. For the main study the results of the survey as distributed between October and December 2015 were used for analysis. Replications were conducted using the results of the surveys distributed at the end of 2013 and the end of 2017 to verify our findings. Although the design of those surveys was quite similar, they were largely based on other 
PO FIT AND EMPLOYER BRAND CLARITY

respondents who rated different organizations (due to the random samples of organizations presented to the individuals) and slightly differed on employer brand elements included.

\section{Sample information ${ }^{1}$}

All responses in this study reflect scores given by individuals who were at least familiar with a particular organization since awareness is a prerequisite for attraction (Cable \& Turban, 2001). Moreover, all individuals have their full top 5 of personal employer brand preferences among the 10 employer brand elements measured on an organizational level which is needed to ensure that all individuals are at least able to achieve maximum PO fit. In addition, we solely included organizations with a minimum of 30 responses, which is an often applied rule of thumb regarding group size in multilevel research (Hox, 1998). In the main study, each individual rated on average 17 organizations whereas this was 11 for the first replication using the 2013 data and 9 for the second replication using the 2017 data. Table 1 provides a detailed description of the sample concerning the main study as well as both replications.

Insert Table 1 about here

\section{Measures}

Person-organization fit. The independent variable PO fit reflects a score that illustrates to what extent the individual's top 5 of personal employer brand preferences is congruent with the organization's employer brand elements (as perceived by the individual), 


\section{PO FIT AND EMPLOYER BRAND CLARITY}

commonly referred to as calculated subjective fit (see e.g. Kristof-Brown \& Billsberry, 2013; Kristof-Brown \& Guay, 2011). Both the individual's top 5 of employer brand preferences and the organization's employer brand elements reflect the following 10 elements that are a subset of instrumental employer brand elements, that are in line with related empirical studies (e.g. Berthon, Ewing \& Hah, 2015; Lievens \& Highhouse, 2003): financially healthy, good training, long-term job security, career progression opportunities, strong management, interesting job content, pleasant working atmosphere, competitive salary and employee benefits, good work-life balance, environmentally and social aware. Since the measurement scale of both scores differed from each other (i.e. the personal preferences were measured through a ranking, while the perceived organizational elements were measured on a 5-point Likert scale), both scores were rescaled into dichotomous variables. The top 5 of personal preferences regarding employer brand elements was recoded such that $0=$ not in top 5 and $1=$ in top 5. Thus, for each of the 10 employer brand elements we indicated whether or not the element was included in the top 5 of the individual. Dichotomization of these scores overcomes the limitations of the inherent ordinal nature of rankings (i.e. the distance between the rank 1 and rank 2 is not necessarily the same as the distance between rank 2 and rank 3 ). The scores that represented the, by the individual, perceived employer brand elements within an organization were originally measured on a 5-point Likert scale $(1=$ not at all true, $5=$ completely true $)^{2}$. The employer brand elements that respondents had to rate were presented to every respondent in a random order. The scores were then transformed into dichotomous scores for which all elements that were answered with a score between 1 and 3 were classified as $0=$ not perceived as present in the organization, and all elements that were answered with a score of either 4 or 5 were classified as $1=$ perceived as present in the organization. The dichotomization here avoids that, in later phases, an element that is among the top 5 of personal preferences (i.e. score $=1$ ) but is not perceived as present within the organization 


\section{PO FIT AND EMPLOYER BRAND CLARITY}

(i.e. original score between 1 and 3) is related to higher levels of PO fit in comparison to an element that is not among the top 5 of personal preferences (i.e. score $=0$ ) and not perceived as present within the organization. After dichotomization, we multiplied the personal and organizational dichotomous scores for each element leaving a score that indicates $1=$ perceived in personal top 5 and perceived as present in the organization and $0=$ either not in top 5 or not present in the organization. Finally, the scores over the 10 elements were added up leaving a score with a maximum value of $5=$ all elements of the personal top 5 are perceived as present in the organization and a minimum value of $0=$ no elements of the top 5 are perceived as present in the organization (see Table 5, Appendix A for an example). A complete fit of all elements was present for $12 \%$ of the cases. Four elements out of the respondent's top 5 was perceived as present in the organization for $7 \%$ of the cases. For $8 \%$ of the cases three elements fitted, two elements fitted for $10 \%$ of the cases, and only one element fitted for $14 \%$ of the cases. For $50 \%$ of the cases in the main study, none of the elements of the respondent's top 5 was perceived as present in the organization.

Employer brand clarity. To examine the clarity of the employer brand the average variance for each of the 10 personal employer brand elements was calculated separately on an organizational-level. A high variance on one employer brand element, indicates that respondents greatly vary about whether the element is or is not present in the organization. To obtain a total employer brand clarity score, we averaged out the variance on each of the included 10 employer brand elements. Since a higher score on employer brand clarity would then mean that the employer brand is less clear (i.e. less consensus about its presence in the organization), we recoded the variable as such that the average variance was subtracted from the number 2 which avoids negative scores and simplifies interpretation in later stages as higher scores imply higher employer brand clarity. 
PO FIT AND EMPLOYER BRAND CLARITY

Employer attractiveness. The dependent variable, employer attractiveness, reflects an individual-per-organization score on the question 'Based on your first impression of the company, to what extent would you like to work for this company?' measured on a 5-point Likert-scale ranging from $1=$ would definitely not like to work for, to $5=$ would very much like to work for. This question was asked before the respondents rated the companies on each of the employer brand elements.

Control variables. Two control variables on the organizational level were included. First, the response rate per organization was included since the calculated score for employer brand clarity represents the variance, which will depend on the number of responses for the organization. The response rate simultaneously gives an indication of the general familiarity with the organization (only those who were familiar with the organization rated the employer brand elements on which the clarity measure based), which controls for the possible effect of familiarity on employer brand clarity. Second, we included an average measure for each employer brand element per organization to be able to disentangle the effect of PO fit and employer brand clarity on employer attractiveness from the effect of these elements. Besides, this measure functions as a control variable for the clarity measure because clarity reflects the average variance which is dependent on the average score per element. On an individual level, age was included as a control variable as age possibly impacts the extent to which people are open to other employers than the one they are currently working for which is expected to influence employer attractiveness.

\section{Analysis}

The data has been analyzed using the lmerTest package with maximum likelihood estimation in RStudio (Kuznetsova, Brockhoff, Christensen, 2017). The model consists of an independent (PO fit) and dependent (employer attractiveness) variable on level 1 reflecting 


\section{PO FIT AND EMPLOYER BRAND CLARITY}

individual-per-organization scores that are nested in both the individual and the organization and a moderating variable (employer brand clarity) that is specified on the organizational level 2 (Figure 1). In order to account for this complex data structure in which the dependent and independent variables are nested within multiple individuals who all provided ratings for more than one organization and the moderating variable is specified at the organizational level, cross-classified multilevel modeling has been used. Cross-classified multilevel modeling allows to account for the variation of the responses that was simultaneously caused by the organizational level as well as individual level, and thereby prevents underrating one of these potentially important levels (Goldstein, 1994). Moreover, multilevel modeling is relatively insensitive to large sample sizes.

Insert Figure 1 about here

\section{RESULTS}

\section{Main study}

We report the results of the main study that are based on the data as collected between October and December 2015.

Descriptive statistics. Table 2 displays the means, standard deviations, and correlations between PO fit, employer brand clarity, employer attractiveness and the control variables. A strong and significant positive correlation was found between PO fit and employer attractiveness $(r=.476, \mathrm{p}<0.01)$, whereas the correlation between PO fit and employer brand clarity was very small and negative $(r=-.03, p<0.01)$. Furthermore, significant yet small correlations were found between employer attractiveness and the average organizational score on each separate employer brand element (ranging from $r=.15$ to $r=$ 


\section{PO FIT AND EMPLOYER BRAND CLARITY}

.22). Particularly high correlations were detected among the separate employer brand elements (ranging from $r=.51$ to $r=.95$ ), which indicates multicollinearity. However, the multicollinearity among these control variables is not considered as an issue for further analysis, since these coefficients will not be interpreted and no problems with respect to a singular correlation matrix occurred.

Insert Table 2 about here

Employer attractiveness. A null model was specified to split the variance into the individual-per-organization level (level 1), the individual level (level 2) and the organizational level (level 2). Intra-class correlation coefficients (ICCs) were calculated as intraorganizational (i.e. correlation in outcome between two responses for the same organization, that were rated by different individuals) and intra-individual (i.e. correlation in outcome between two responses of the same individual for different organizations) correlations by dividing either the organizational or the individual random effect variance by the total variance (i.e. the sum of the three variance components). The ICC value for the organizational level was .06 , meaning that $6 \%$ of the variance within employer attractiveness is attributable to the organizational grouping variable. Although this ICC is relatively low, since $6 \%$ of the variance is explained by the organizational level and strong theoretical reasons exist to assume the impact of the organizational level, we proceed with including the organizational level throughout the analysis. The ICC value for the individual level was .35, which indicates that $35 \%$ of the variance within organizational attractiveness is attributable to the individual grouping variable. In the second step, the control variables were added (Model 2). Good training $(\gamma=-0.27, t=-2.23, p<0.05)$, interesting job content $(\gamma=0.88, t=6.28, p<0.01)$, a 
PO FIT AND EMPLOYER BRAND CLARITY

pleasant working atmosphere $(\gamma=0.51, t=4.39, p<0.01)$, good work-life balance $(\gamma=-0.20$, $t=-2.01, p<0.05)^{4}$, and the sample size used for the clarity measure $(\gamma=0.00, t=2.27, p<$ 0.05) appeared to be significantly related to employer attractiveness. Including the control variables led to a significant improvement the model $\left(\Delta \chi^{2}(12)=359, p<0.01\right)$ (Table 3).

Insert Table 3 about here

PO fit and employer attractiveness. The relationship between PO fit (i.e. content) and employer attractiveness was examined by adding PO fit to the model (Model 3). This third model showed a significant model improvement $\left(\Delta \chi^{2}(1)=4224.20, p<0.01\right)$. In line with Hypothesis 1, the model showed a significant positive relationship between PO fit and employer attractiveness $(\gamma=0.29, t=68.24, p<0.01)$.

Moderation effect of employer brand clarity. The total model was tested in which the interaction effect between PO fit and employer brand clarity was added to the model. In comparison to the third model, this model again showed a significant model improvement $\left(\Delta \chi^{2}(2)=42.00, p<0.01\right)$. The relationship between PO fit and employer attractiveness was still significant $(\gamma=0.42, t=15.28, p<0.01)$. Moreover, the results showed a significant interaction effect of PO fit and employer brand clarity $(\gamma=-0.12, t=-5.05, p<0.01)^{3}$. Contrary to Hypothesis 2, which predicted a positive interaction effect, the interaction effect found was negative which indicates that for low levels of PO fit high levels of employer brand clarity increase employer attractiveness, whereas for high levels of PO fit high levels of employer brand clarity decrease employer attractiveness (Figure 2). 


\section{Replications}

To verify our findings, we replicated the study across several years by using the data of the Randstad Employer Brand Research as collected in 2013 and 2017.

Descriptive statistics. The data of the first replication, based on the Randstad Employer Brand Research as collected in 2013, shows a strong positive correlation between PO fit and employer attractiveness $(r=.466, \mathrm{p}<.01)$. The correlation between PO fit and employer brand clarity $(r=.064, p<.01)$ was - contrary to our expectations - slightly positive and significant. The second replication, based on the data of the Randstad Employer Brand Research as collected in 2017, only showed a strong and positive correlation between PO fit and employer attractiveness $(r=.511, p<.01)$. Note that the lack of any correlation (or different correlations) between PO fit and employer brand clarity possibly occurred due to the usage of single-level correlations for multilevel variables.

Total model. Table 4 shows the total model results for the performed replications. The total model of the first replication using the data of the Randstad Employer Brand Research as collected in 2013 showed similar results as the main study. PO fit positively related to employer attractiveness $(\gamma=0.51, t=17.43, p<0.01)$. The moderation effect of employer brand clarity on the relationship between PO fit and employer attractiveness was again negative and significant $(\gamma=-0.20, t=-7.76, p<0.01$, Figure 3$)$. For the second replication based on the Randstad Employer Brand Research data as collected in 2017, results are similar as well. PO fit, again, positively related to employer attractiveness $(\gamma=0.51, t=14.87, p<$ 
PO FIT AND EMPLOYER BRAND CLARITY

0.01) and employer brand clarity negatively moderated the relationship between PO fit and employer attractiveness $(\gamma=-0.16, t=-4.74, p<0.01$, Figure 4).

Insert Table 4 about here

Insert Figure 3 about here

Insert Figure 4 about here

\section{DISCUSSION}

Building on the HRM system strength theory allowed to incorporate both content and process as determinants of the effectiveness of employer brands, which offered a refined perspective on employer branding research and produced an enriched understanding of the relationship between employer brand(ing) and employer attractiveness. We argued that a strong and ultimately effective employer brand comprises unique elements that incorporates the individual preferences of the targeted workforce, is clearly promoted internally and externally and thereby strives for an optimal integration between the employer brand content and the process of employer branding. This extended perception of a strong employer brand 


\section{PO FIT AND EMPLOYER BRAND CLARITY}

allowed to investigate whether PO fit (i.e. content) related to employer attractiveness and whether employer brand clarity (i.e. process) moderated this relationship.

The findings revealed a strong and positive relationship between PO fit and employer attractiveness over and above the average score per organization on each of the included employer brand elements (Hypothesis 1). This result confirms the idea that individuals are searching for environments that fulfill their needs and reinforce their selves and is in line with prior findings that revealed a positive relationship between PO fit (based on value congruence in contrast to needs-supply fit based on employer brand elements) and organizational attractiveness (Chapman \& Mayers, 2015, Chapman et al., 2005, Uggerslev et al., 2012). The operationalization of PO fit as the fit between an individual's top 5 preferences of instrumental employer brand elements and the individual's perception of the elements that the organization supplies, brought about a needs-supply perspective on assessing PO fit between individuals and their possible employers that suits the most recent advancements in recruitment. Moreover, this operationalization of PO fit offers a renewed measurement of the employer brand content that could incorporate individual preferences as well as organizational-level employer brand elements from a value congruence (i.e. symbolic elements) and needs-supply (i.e. instrumental elements) perspective.

Alongside the content of the employer brand, the process of employer branding is also relevant to establish an effective employer brand (cf. Bowen \& Ostroff, 2004). Employer brand clarity was considered as a crucial element of the employer branding process and thereby hypothesized to produce more pronounced effects of PO fit (i.e. content) on employer attractiveness. Contrary to this hypothesis (Hypothesis 2), we found a negative yet small moderation effect of employer brand clarity on the relationship between PO fit and employer attractiveness, which suggested that employer brand clarity slightly attenuated the relationship between PO fit and employer attractiveness. The combination of high PO fit and high 


\section{PO FIT AND EMPLOYER BRAND CLARITY}

employer brand clarity, therefore, did not relate to the highest level of employer attractiveness (cf. Bowen \& Ostroff, 2004). The combination low PO fit and low employer brand clarity was linked to slightly lower levels of employer attractiveness than the combination low PO fit and high employer brand clarity. In absence of PO fit, one might argue that individuals search for other signals provided by the organization to decide on employer attractiveness. Employer brand clarity can provide such signal as it is suggested that high levels of employer brand clarity decrease the perceived risk associated with working for the employer and implies a higher quality of employment (Wilden et al., 2010). Despite low PO fit, high levels of employer brand clarity perhaps compensate such that the employer attractiveness is higher than in case of low employer brand clarity. This is in line with the findings of Gregory, Meade \& Thompson (2013) which confirm that in case of low levels of person-job fit, attitudes towards organizations are more positive when applicants have high levels of job information compared to low levels of job information. The aforementioned illustrates that employer brand clarity might partly compensate for the absence of PO fit and, therefore, stresses the potential importance of the employer brand process. However, in the situation of high PO fit, the opposite appeared to be true: high levels of employer brand clarity slightly lowered employer attractiveness, in comparison to low levels of employer brand clarity (although in both conditions employer attractiveness remains high). Perhaps the combination of high or even maximum PO fit and high levels of employer brand clarity that raises confidence about one's PO fit, lowers employer attractiveness as individuals might perceive the employer brand as 'too good to be true'. Another conceivable explanation would be that individuals in these circumstances consider their PO fit so evident that they presume that plenty other individuals will also experience such high levels of PO fit which decreases the value of high levels of PO fit whilst determining employer attractiveness. 


\section{PO FIT AND EMPLOYER BRAND CLARITY}

Taken together, the aforementioned findings demonstrate how employer brand clarity slightly moderates the strong positive relationship between PO fit and employer attractiveness. Thereby this study expands the common practice whereby strong employer brands are regarded as those that comprise numerous universally appealing employer features and sheds a new light on the establishment of employer attractiveness. PO fit and employer brand clarity interact whilst influencing individuals' attitudes with regard to employer attractiveness and the presumably the accompanied job choice decisions. To aid individuals' decision making and generate high levels of employer attractiveness, organizations should thus create an employer brand that is unique, incorporates the relevant individual's preferences of the targeted workforce, is clearly promoted across internal and external audiences, and thereby strives for integration between the employer brand content and the process of employer branding.

\section{Limitations and future research directions}

This study was subject to several limitations, which mostly occurred due to the use of secondary data that was not collected for the purpose of research. First, the data we used was cross-sectional. Although both independent variables were proxies rather than self-reported measures, which to a great extent overcomes common method bias as a main constraint of cross-sectional data (Podsakoff, MacKenzie, Lee, \& Podsakoff, 2003; Spector, 2019), the design limits the extent to which the findings truly demonstrate cause-and-effect relationships. Second, the measures included in this study were based on single item measures rather than validated scales. However, in case of affective attitudes such as employer attractiveness, the predictive validity of single item measures is equal to that of multiple-item measures due to the uniform and easily understandable content of the items (Bergkvist \& Rossiter, 2007). Third, the included measurements in the dataset were challenging for calculating PO fit. The 


\section{PO FIT AND EMPLOYER BRAND CLARITY}

personal preferences with regard to an employer brand were measured as a ranking (that is ordinal in nature) of 18 elements, whereas the perceptions of organizational employer brand elements were measured on a Likert-scale and included solely 10 elements. Albeit, several selection criteria and the usage of dichotomization enabled to resolve those data complexities, we acknowledge that this approach implies several risks being significant loss of information on individual differences as well as a slightly higher chance for Type I errors due to inflated standard errors as compared to continuous variables (MacCallum, Zhang, Preacher \& Rucker, 2002). Moreover, the dichotomization hinders the usage of polynomial regression techniques that would have given more detailed insights in how person-organization fit predicts employer attractiveness (Edwards \& Parry, 1993). Ideally, the dataset would have provided continuous measures of both individual preferences and organizational perceptions that prevents the usage of dichotomization and would allow to conduct polynomial regression analysis or even included direct perceived fit measures (see Kristof-Brown \& Guay, 2011). Fourth, although employer brand clarity seems to be a prominent component of the employer branding process, we acknowledge that other process-related features (e.g. consistency or credibility, Wilden et al., 2010) may also relate to employer brand effectiveness. Last, the organizations included in the dataset were selected either based on their size (i.e. larger than 1000 employees) or are seen as impactful Belgian companies, which implied that those organizations were not necessarily concerned with employer branding. Therefore, solely cautious conclusions can be drawn based on the findings of this study.

Future research may overcome many of the aforementioned limitations by collecting data purely for the purpose of research. In this regard, future research may adopt a longitudinal or (quasi-)experimental design with an even more advanced measurement of PO fit based on both instrumental (i.e. needs-supply) and symbolic (i.e. value congruence) employer brand elements that allows to perform polynomial regressions. In addition, future 


\section{PO FIT AND EMPLOYER BRAND CLARITY}

studies may deepen our understanding with regard to individual employer brand preferences by examining whether employer brands that are consciously targeted towards individuals' preferences result in higher applicant pool quality and thereby even decrease selection costs which benefits the efficiency of the employer brand and organizational outcomes.

Furthermore, one may shed light on the interacting content and process of the employer brand in future research. To this extent, the branding literature may provide interesting angles that may further our understanding of the employer branding process and reveal the dynamics behind the unexpected negative interaction between PO fit and employer brand clarity.

\section{Practical implications}

The practical implications of this study are twofold. First, this study emphasizes the relevance of tailoring an employer brand towards the employer brand preferences of the targeted workforce, since PO fit (based on employer brand elements) is linked to employer attractiveness, over and above single employer brand elements. Rethinking the employer brand content as such may allow individuals to assess whether the organization particularly values the employer brand elements they are searching for and therefore self-select out of the recruitment process if the organization does not conform to their desires. Individuals who deliberately decide to apply for the organization will likely show a better PO fit (based on employer brand elements), which might enhance the applicant pool quality and consequently lower selection costs (Breaugh \& Starke, 2000; Dineen, Ling, Ash, \& DelVecchio, 2007; Tumasjan et al., 2020; Weller, Michailik, \& Mühlbauer, 2014). Research has repeatedly found that high PO fit based on values has a positive impact on job satisfaction, job performance, organizational commitment and well-being (Edwards \& Shipp, 2007; Chapman \& Mayers, 2015), which might apply to PO fit based on employer brand elements as well. Second, the process of employer branding deserves the attention of practitioners. Establishing a clear view 


\section{PO FIT AND EMPLOYER BRAND CLARITY}

of the employer brand that is perceived unanimously across individuals provides a positive signal that, in absence of PO fit, strengthens employer attractiveness. This is particularly relevant for organizations that encounter excessive labor shortages as clear communication about the employer brand attributes may allow to attract a broader range of applicants, regardless of their fit. To assess the clarity of their employer brand (i.e. whether variability among individuals' perceptions of the employer brand content is low), organizations may include employer brand elements in employee surveys and market research. Furthermore, organizations may need to strengthen collaboration between the HR and marketing department, which enables to create a strong and effective employer brand that optimally combines the employer brand content with the employer branding process (Bowen \& Ostroff, 2004; Moroko \& Uncles, 2008).

\section{Conclusion}

To overcome the shortages on the labor market, many organizations to date invest in employer branding to enhance their employer attractiveness. This study offers a renewed perspective by integrating the content of the employer brand and the process of employer branding and argues that the integration of process and content is needed to optimize employer attractiveness. Our results reveal that PO fit, as an extended measure of employer brand content that incorporates individual differences, strongly positively relates to employer attractiveness above and beyond universally appealing employer brand elements (such as salary or career opportunities). Contrary to our expectations, employer brand clarity negatively moderated the relationship between PO fit and employer attractiveness. This prompts interesting questions for future research that may in-depth assess how content and process interact in determining the effectiveness of employer brands. 


\section{REFERENCES}

Aiyar, S., Ebeke, C., \& Shao, X. (2016). The Impact of Workforce Aging on European Productivity. IMF Working paper, 16/238: 1-29.

Ambler, T., \& Barrow, S. (1996). The employer brand. Journal of brand management, 4(3): 185-206. doi:10.1057/bm.1996.42

Backhaus, K., \& Tikoo, S. (2004). Conceptualizing and researching employer branding. Career development international, 9(5): 501-517. doi:10.1108/13620430410550754

Bergkvist, L., \& Rossiter, J. R. (2007). The predictive validity of multiple-item versus singleitem measures of the same constructs. Journal of marketing research, 44(2): 175-184. doi:10.1509/jmkr.44.2.175

Berthon, P., Ewing, M., \& Hah, L. L. (2005). Captivating company: dimensions of attractiveness in employer branding. International journal of advertising, 24(2), 151172. doi:10.1080/02650487.2005.11072912

Biswas, M. K., \& Suar, D. (2016). Antecedents and consequences of employer branding. Journal of Business Ethics, 136(1): 57-72. doi:10.1007/s10551-014-2502-3

Bowen, D. E., \& Ostroff, C. (2004). Understanding HRM-firm performance linkages: The role of the "strength" of the HRM system. Academy of management review, 29(2): 203-221. doi:10.5465/amr.2004.12736076

Breaugh, J. A., \& Starke, M. (2000). Research on employee recruitment: So many studies, so many remaining questions. Journal of management, 26(3): 405-434. doi:10.1177/014920630002600303

Cable, D. M., \& Judge, T. A. (1996). Person-organization fit, job choice decisions, and organizational entry. Organizational behavior and human decision processes, 67(3): 


\section{PO FIT AND EMPLOYER BRAND CLARITY}

294-311. doi:10.1006/obhd.1996.0081

Cable, D. M., \& Turban, D. B. (2001). Establishing the dimensions, sources and value of job seekers' employer knowledge during recruitment. Research in personnel and human resources management, 115-163. doi:10.1016/S0742-7301(01)20002-4

Carless, S. A. (2005). Person-job fit versus person-organization fit as predictors of organizational attraction and job acceptance intentions: A longitudinal study. Journal of Occupational and Organizational Psychology, 78(3), 411-429. doi:10.1348/096317905X25995

Celani, A., \& Singh, P. (2011). Signaling theory and applicant attraction outcomes. Personnel review, 40(2): 222-238. doi:10.1108/00483481111106093

Chapman, D. S., Uggerslev, K. L., Carroll, S. A., Piasentin, K. A., \& Jones, D. A. (2005). Applicant attraction to organizations and job choice: a meta-analytic review of the correlates of recruiting outcomes. Journal of applied psychology, 90(5): 928-944. doi:10.1037/0021-9010.90.5.928

Chapman, D. S., \& Mayers, D. (2015). Recruitment processes and organizational attraction. In: I. Nikolaou \& Oostrom J.K. (Eds.) Employee Recruitment, Selection, and Assessment: Contemporary Issues for Theory and Practice: 27-42. Hove: Psychology Press.

Collins C.J. \& Kanar A.M. (2014). Employer Brand Equity and Recruitment Research. In: K.Y.T. Yu \& D.M. Cable (Eds.) The Oxford Handbook of Recruitment: 284 -297. Oxford: Oxford University Press.

Collins, C. J., \& Stevens, C. K. (2002). The relationship between early recruitment-related activities and the application decisions of new labor-market entrants: a brand equity approach to recruitment. Journal of applied psychology, 87(6): 1121-1133. doi:10.1037/0021-9010.87.6.1121 


\section{PO FIT AND EMPLOYER BRAND CLARITY}

Connelly, B. L., Certo, S. T., Ireland, R. D., \& Reutzel, C. R. (2011). Signaling theory: A review and assessment. Journal of Management, 37(1): 39-67. doi:10.1177/0149206310388419

Dineen, B. R., Ling, J., Ash, S. R., \& DelVecchio, D. (2007). Aesthetic properties and message customization: navigating the dark side of web recruitment. Journal of applied psychology, 92(2): 356. doi:10.1037/0021-9010.92.2.356

Edwards, M. R. (2009). An integrative review of employer branding and OB theory. Personnel review, 39(1): 5-23. doi:10.1108/00483481011012809.

Edwards, J. R., \& Parry, M. E. (1993). On the use of polynomial regression equations as an alternative to difference scores in organizational research. Academy of Management journal, 36(6): 1577-1613. doi:10.5465/256822

Edwards, J. R., \& Shipp, A. I. (2007). The relationship between person-environment fit and outcomes: An integrative theoretical framework. In C. Ostroff \& T. A. Judge (Eds.), Perspectives on organizational fit: 209-258. San Francisco: Jossey-Bass.

Erdem, T., \& Swait, J. (1998). Brand equity as a signaling phenomenon. Journal of consumer psychology, 7(2): 131-157.doi:10.1207/s15327663jcp0702_02

Eurostat (2019) People in the EU - population projections. Retrieved on 7 January 2020 from https://ec.europa.eu/eurostat/web/population-demography-migrationprojections/population-projections-/main-tables

Goldstein, H. (1994). Multilevel cross-classified models. Sociological Methods \& Research, 22(3): 364-375. doi:10.1177/0049124194022003005

Gregory, C. K., Meade, A. W., \& Thompson, L. F. (2013). Understanding internet recruitment via signaling theory and the elaboration likelihood model. Computers in Human Behavior, 29(5): 1949-1959. doi:10.1016/j.chb.2013.04.013

Hox, J. (1998). Multilevel modeling: When and why. In Classification, data analysis, and 


\section{PO FIT AND EMPLOYER BRAND CLARITY}

data highways: 147-154. Berlin: Springer.

Kristof, A. L. (1996). Person-organization fit: An integrative review of its conceptualizations, measurement, and implications. Personnel psychology, 49(1), 1-49. doi: 10.1111/j.1744-6570.1996.tb01790.x

Kristof-Brown, A.L., \& Billsberry, J. (2014). Fit for the future. In A.L. Kristof-Brown \& J. Billsberry (Eds.), Organizational fit: key issues and new directions: 1-20. New York: John Wiley and Sons.

Kristof-Brown, A. L., \& Guay, R. P. (2011). Person-environment fit. In S. Zedeck (Ed.), American Psychological Association handbook of industrial and organizational psychology: 3-50. Washington DC: American Psychological Association.

Kuznetsova A., Brockhoff P.B., Christensen R.H.B. (2017). lmerTest Package: Tests in Linear Mixed Effects Models. Journal of Statistical Software, 82(13), 1-26. doi: 10.18637/jss.v082.i13.

Lievens, F. (2007). Employer branding in the Belgian Army: The importance of instrumental and symbolic beliefs for potential applicants, actual applicants, and military employees. Human Resource Management, 46(1): 51-69. doi:10.1002/hrm.20145

Lievens, F., \& Highhouse, S. (2003). The relation of instrumental and symbolic attributes to a company's attractiveness as an employer. Personnel psychology, 56(1): 75-102. doi:10.1111/j.1744-6570.2003.tb00144.x

Lievens, F., \& Slaughter, J. E. (2016). Employer image and employer branding: What we know and what we need to know. Annual Review of Organizational Psychology and Organizational Behavior, 3: 407-440. doi:10.1146/annurev-orgpsych-041015-062501 Lievens, F., Van Hoye, G., \& Anseel, F. (2007). Organizational identity and employer image: Towards a unifying framework. British Journal of Management, 18: 45-59. doi:10.1111/j.1467-8551.2007.00525.x 


\section{PO FIT AND EMPLOYER BRAND CLARITY}

MacCallum, R. C., Zhang, S., Preacher, K. J., \& Rucker, D. D. (2002). On the practice of dichotomization of quantitative variables. Psychological methods, 7(1), 19. doi:10.1037/1082-989x.7.1.19

Moroko, L., \& Uncles, M. D. (2008). Characteristics of successful employer brands. Journal of Brand Management, 16(3): 160-175. doi:10.1057/bm.2008.4

Murphy, K. R., \& Tam, A. P. (2004). The decisions job applicants must make: Insights from a Bayesian perspective. International Journal of Selection and Assessment, 12(1-2), 66-74. doi:10.1111/j.0965-075X.2004.00264.X

Phillips, J. M., \& Gully, S. M. (2015). Multilevel and strategic recruiting: Where have we been, where can we go from here?. Journal of Management, 41(5): 1416-1445. doi:10.1177/0149206315582248

Podsakoff, P. M., MacKenzie, S. B., Lee, J. Y., \& Podsakoff, N. P. 2003. Common method biases in behavioral research: a critical review of the literature and recommended remedies. Journal of applied psychology, 88(5): 879-903. doi:10.1037/00219010.88 .5 .879

Rynes, S. L., Bretz, R. D., \& Gerhart, B. (1991). The importance of recruitment in job choice: A different way of looking. Personnel psychology, 44(3): 487-521. doi:10.1111/j.1744-6570.1991.tb02402.x

Shrout, P. E., \& Rodgers, J. L. (2018). Psychology, science, and knowledge construction: Broadening perspectives from the replication crisis. Annual Review of Psychology, 69: 487-510. doi:10.1146/annurev-psych-122216-011845

Singh, K., Ang, S. H., \& Leong, S. M. (2003). Increasing replication for knowledge accumulation in strategy research. Journal of Management, 29(4): 533-549. doi:10.1016/S0149-2063_03_00024-2 


\section{PO FIT AND EMPLOYER BRAND CLARITY}

Spector, P. E. (2019). Do Not Cross Me: Optimizing the Use of Cross-Sectional Designs. Journal of Business and Psychology, 34(2), 125-137. doi:10.1007/s10869-018-096138

Spence, M. (1973). Job market signaling. Quarterly Journal of Economics, 87: 355-374. doi:10.2307/1882010

Taylor, M. S. \& Collins, C. J. (2000). Organizational recruitment: Enhancing the intersection of research and practice. In C. L. Cooper \& E. A. Locke (Eds.) Industrial and Organizational Psychology: 304-334. Oxford: Blackwell Publishing, Ltd.

Tumasjan, A., Kunze, F., Bruch, H., \& Welpe, I. M. (2020). Linking employer branding orientation and firm performance: Testing a dual mediation route of recruitment efficiency and positive affective climate. Human Resource Management, 59(1), 83-99. doi:10.1002/hrm.21980

Uggerslev, K. L., Fassina, N. E., \& Kraichy, D. (2012). Recruiting through the stages: A meta-analytic test of predictors of applicant attraction at different stages of the recruiting process. Personnel Psychology, 65(3): 597-660. doi:10.1111/j.17446570.2012.01254.x

Van Hoye, G., Bas, T., Cromheecke, S., \& Lievens, F. (2013). The instrumental and symbolic dimensions of organisations' image as an employer: A large-scale field study on employer branding in Turkey. Applied Psychology, 62(4): 543-557. doi:10.1111/j.1464-0597.2012.00495.x

Volopne, S.D., Thomas, K.M., Sinisterra, P. \& Johnson, L. (2014). Targeted Recruiting: Identifying Future Employees. In: K.Y.T. Yu \& D.M. Cable (Eds.) The Oxford Handbook of Recruitment: 110-125. Oxford, UK: Oxford University Press. 
PO FIT AND EMPLOYER BRAND CLARITY

Weller, Michailik, \& Mühlbauer, (2014). Recruitment Source Implications for Organizational Tenure. K.Y.T. Yu \& D.M. Cable (Eds.) The Oxford Handbook of Recruitment: 139160. Oxford, UK: Oxford University Press.

Wilden, R., Gudergan, S., \& Lings, I. (2010). Employer branding: strategic implications for staff recruitment. Journal of Marketing Management, 26(1-2): 56-73. doi:10.1080/02672570903577091

\section{FOOTNOTES}

(1) The used sample is based on a subset of a dataset that is collected in the context of the Randstad Employer Brand Research. Respondents were only included in our study if all the necessary data was available and they met the requirements of our study.

(2) The scores represent responses to the question: 'In order to determine a company's attractiveness as an employer, we would like to know your impression of this company, based on the factors below. Please express how you think these companies perform as an employer. We would like to know your impression, so you do not need to have any experience with the company. Please rate the organization below on a scale from 1 (not at all true) to 5 (completely true)'.

(3) Analyses for the total model were repeated for different measures of PO fit. Including anchor " 3 " for the organizational attributes in the 'present' category led to similar results (PO fit: $\gamma=.42, \mathrm{SD}=.03, p<.001$; moderation-effect: $\gamma=-.13, \mathrm{SD}=.03, p<.001)$. Comparable results (PO fit: $\gamma=.32, \mathrm{SD}=.06, p<.001$; moderation-effect: $\gamma=-.16, \mathrm{SD}=.05, p<.001$ ), based on 4075 responses that were nested in 1107 individuals and 235 organizations, were found when all "3" ratings for organizational attributes were excluded from the dataset. 


\section{FIGURE 1}

Level 2: Organization

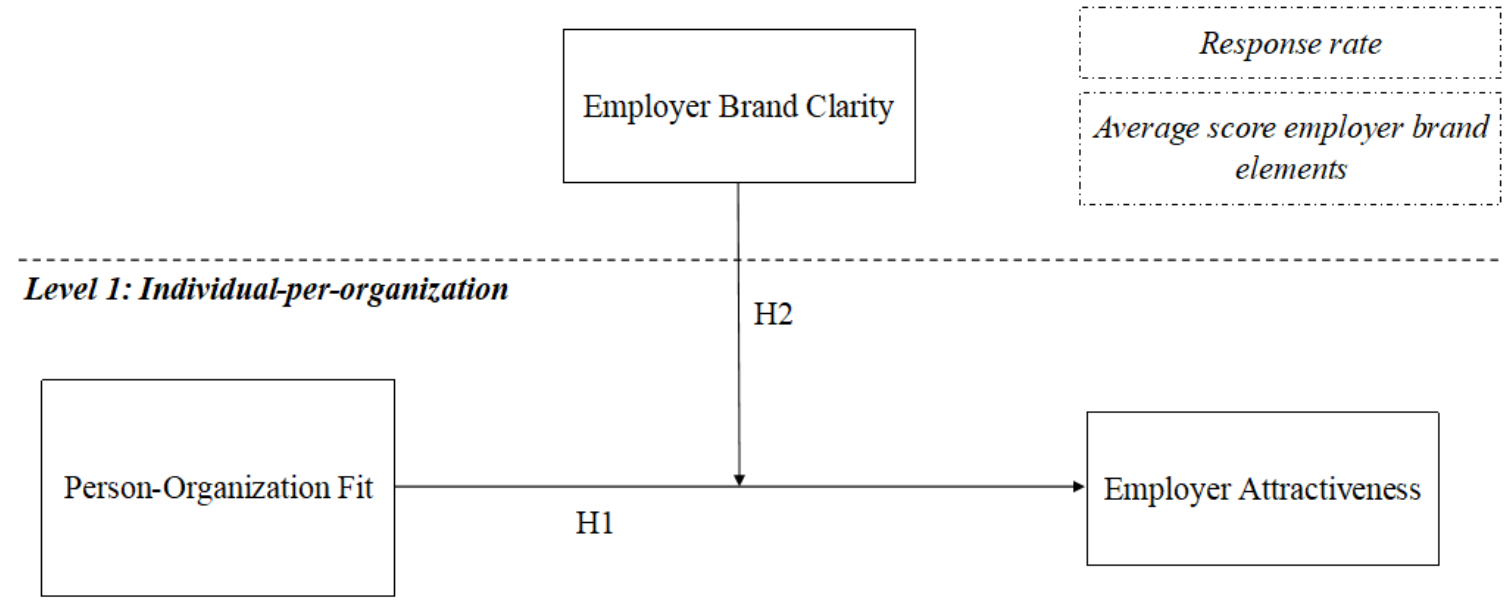

Level 2: Individual

Age

Note: the variables in dotted boxes are included as control variables

Figure 1. Research model 
FIGURE 2

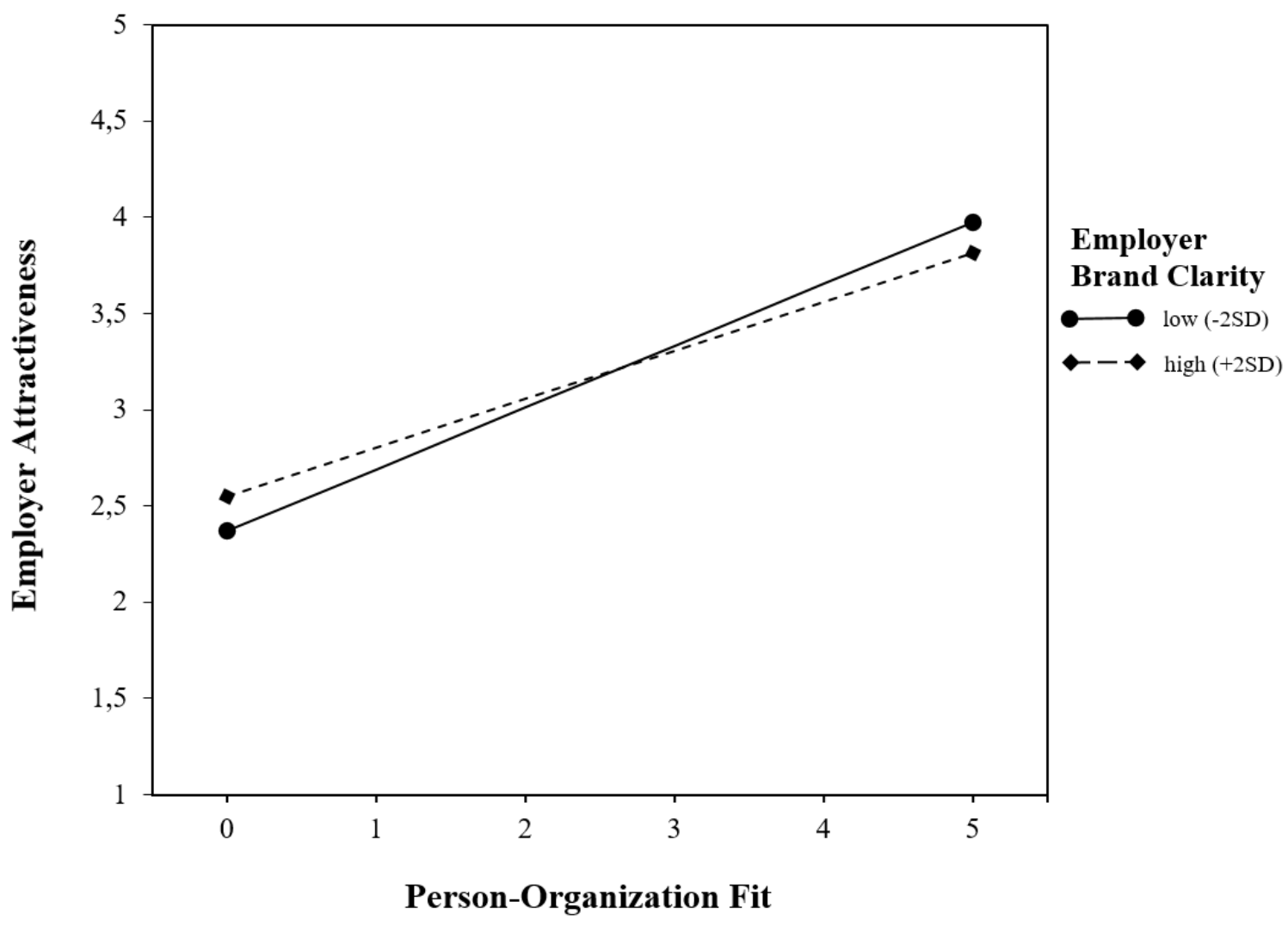

Figure 2. Plot interaction effect PO fit*employer brand clarity main study 
FIGURE 3

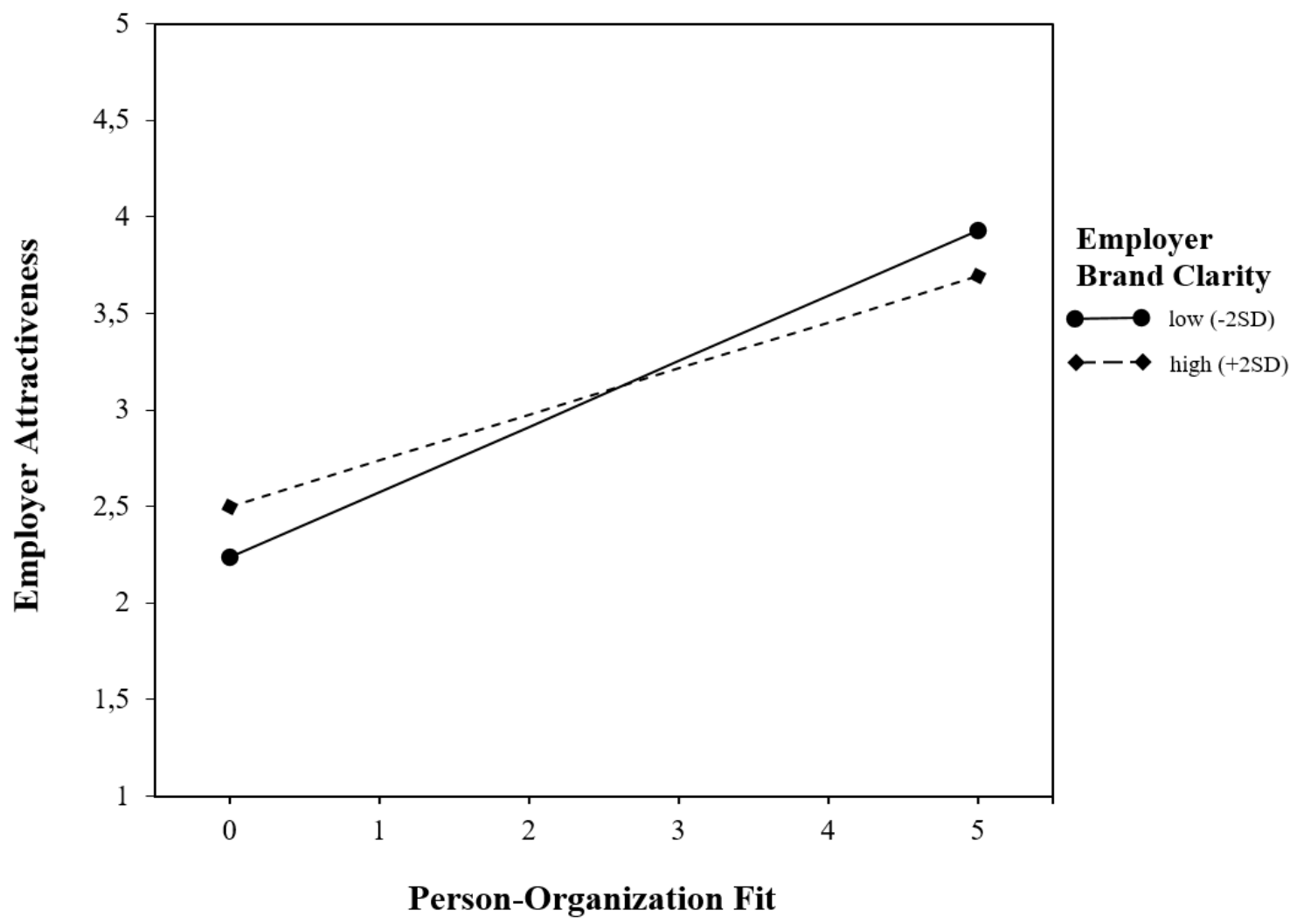

Figure 3. Plot interaction effect PO fit*employer brand clarity replication 2013 
FIGURE 4

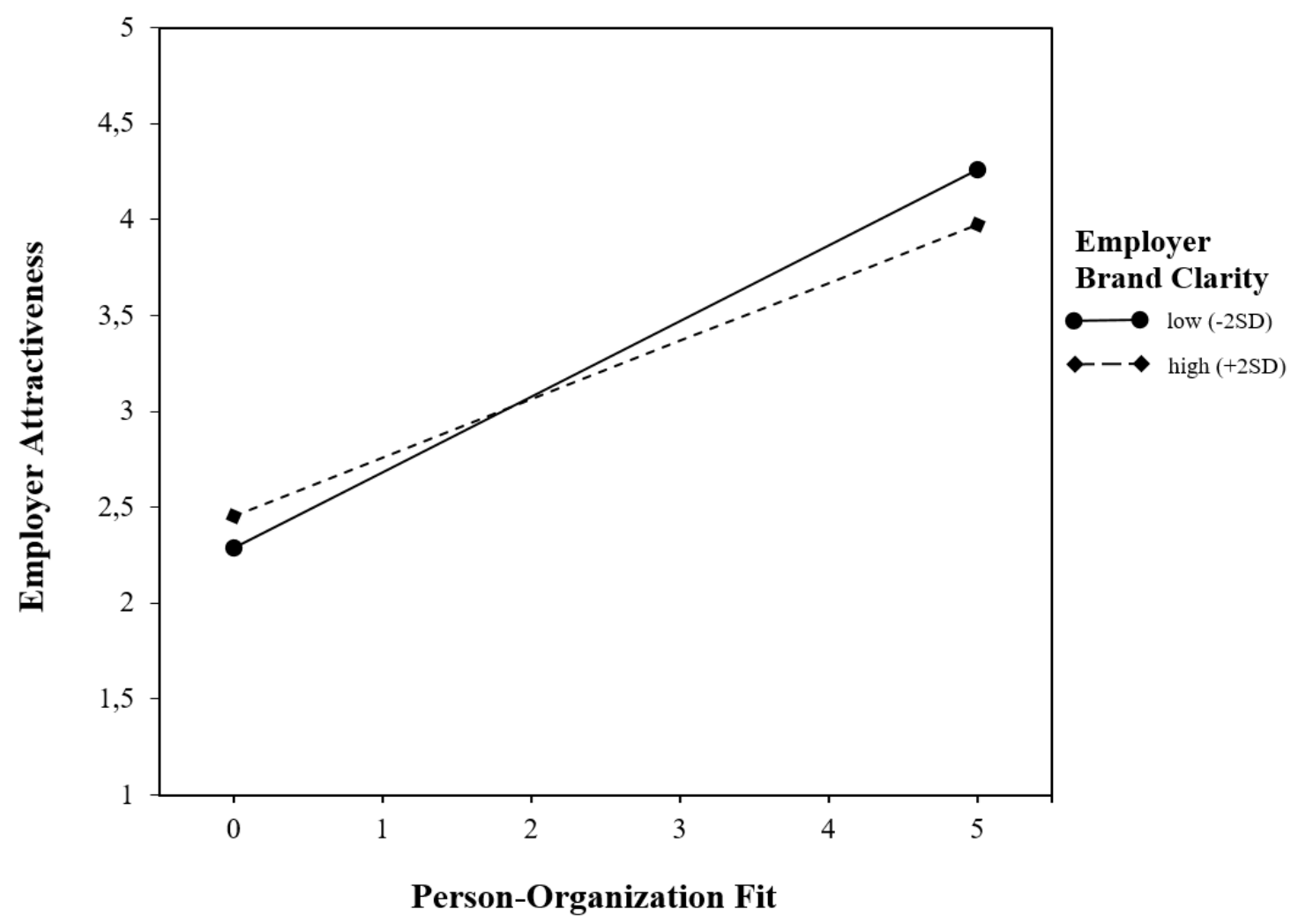

Figure 4. Plot interaction effect PO fit*employer brand clarity replication 2017 
PO FIT AND EMPLOYER BRAND CLARITY

Table 1. Sample description

\begin{tabular}{|c|c|c|c|}
\hline & Main study & $\begin{array}{c}\text { Replication } \\
2013\end{array}$ & $\begin{array}{c}\text { Replication } \\
2017\end{array}$ \\
\hline Responses (N) & 24317 & 30942 & 11539 \\
\hline Individuals (N) & 2123 & 2845 & 1259 \\
\hline Gender (\%female) & $54.3 \%$ & $54.2 \%$ & $44.8 \%$ \\
\hline Age (mean $(\mathrm{SD}))$ & $36.08(12.67)$ & $34.54(12.37)$ & $35 *$ \\
\hline \multicolumn{4}{|l|}{ Highest level of education (\%) } \\
\hline No diploma & $1.8 \%$ & NA & NA \\
\hline Primary education/Secondary education & $47.6 \%$ & $36.8 \%$ & NA \\
\hline Further education, not at university level & $32.4 \%$ & $39.8 \%$ & NA \\
\hline University & $15.7 \%$ & $18.5 \%$ & NA \\
\hline Post university degree & $2.5 \%$ & $2.3 \%$ & NA \\
\hline \multicolumn{4}{|l|}{ Current job status $(\%)$} \\
\hline Unemployed, looking for work & $12.6 \%$ & $12.2 \%$ & $11.5 \%$ \\
\hline Employed & $71.6 \%$ & $68.2 \%$ & $70.9 \%$ \\
\hline Student & $15.8 \%$ & $19.5 \%$ & $17.6 \%$ \\
\hline Organizations(N) & 235 & 256 & 196 \\
\hline \multicolumn{4}{|l|}{ Sector $(\%)$} \\
\hline Profit & $97.4 \%$ & $83.3 \%$ & $87.3 \%$ \\
\hline Non-profit & $2.6 \%$ & $16.7 \%$ & $12.7 \%$ \\
\hline
\end{tabular}

$N A=$ not available, *only a categorical measure of age was available 


\section{PO FIT AND EMPLOYER BRAND CLARITY}

Table 2. Descriptive statistics and Pearson correlations main study

\begin{tabular}{|c|c|c|c|c|c|c|c|c|c|c|c|c|c|c|c|c|c|}
\hline & Variables & $\mathbf{M}$ & SD & 1 & 2 & 3 & 4 & 5 & 6 & 7 & 8 & 9 & $\mathbf{1 0}$ & 11 & 12 & 13 & 14 \\
\hline 3 & Employer brand clarity & 1.16 & 0.12 & .01 & $-.03^{* *}$ & -- & & & & & & & & & & & \\
\hline 5 & Age & 41.45 & 14.59 & $-.02^{*}$ & $-.03^{* *}$ & $.03^{* *}$ & $-.09^{* *}$ & -- & & & & & & & & & \\
\hline 6 & Financially healthy & 3.31 & 0.25 & $.17^{* *}$ & $.19^{* *}$ & -.00 & $.10^{* *}$ & .00 & -- & & & & & & & & \\
\hline 7 & Good training & 3.06 & 0.28 & $.18^{* *}$ & $.22^{* *}$ & $.07^{* * *}$ & $-.26^{* *}$ & $.04^{* *}$ & $.53^{* *}$ & -- & & & & & & & \\
\hline 10 & Strong management & 3.32 & 0.23 & $.20^{* *}$ & $.21^{* *}$ & $-.05^{* *}$ & $.07^{* *}$ & .01 & $.89^{* *}$ & $.71^{* *}$ & $.73^{* *}$ & $.80^{* *}$ & -- & & & & \\
\hline 11 & Interesting job content & 3.02 & 0.31 & $.22^{* *}$ & $.23^{* *}$ & $.08^{* *}$ & $-.20^{* *}$ & $.03^{* *}$ & $.57^{* *}$ & $.93^{* *}$ & $.75^{* *}$ & $.94^{* *}$ & $.75^{* *}$ & -- & & & \\
\hline 12 & Pleasant working atmosphere & 3.01 & 0.21 & $.19^{* *}$ & $.19^{* *}$ & $.15^{* *}$ & -.01 & .00 & $.67^{* *}$ & $.64^{* *}$ & $.69^{* *}$ & $.71^{* *}$ & $.73^{* *}$ & $.78^{* *}$ & -- & & \\
\hline 13 & Competitive salary and benefits & 3.04 & 0.29 & $.19^{* *}$ & $.22^{* *}$ & $.09^{* *}$ & $-.24^{* *}$ & $.04^{* *}$ & $.57^{* *}$ & $.95^{* *}$ & $.79^{* *}$ & $.95^{* *}$ & $.74^{* *}$ & $.93^{* *}$ & $.66^{* *}$ & -- & \\
\hline 14 & Good work-life balance & 2.97 & 0.16 & $.15^{* *}$ & $.16^{* *}$ & $.15^{* *}$ & $-.04^{* *}$ & .00 & $.55^{* *}$ & $.57^{* *}$ & $.72^{* *}$ & $.61^{* *}$ & $.53^{* *}$ & $.58^{* *}$ & $.69^{* *}$ & $.60^{* *}$ & -- \\
\hline 15 & $\begin{array}{l}\text { Environmentally and socially } \\
\text { aware }\end{array}$ & 2.87 & 0.22 & $.15^{* *}$ & $.14^{* * *}$ & $.22^{* *}$ & $-.10^{* *}$ & $.02^{*}$ & $.53^{* *}$ & $.51^{* *}$ & $.65^{* *}$ & $.55^{* *}$ & $.51^{* *}$ & $.55^{* *}$ & $.70^{* *}$ & $.46^{* *}$ & $.62^{* *}$ \\
\hline
\end{tabular}




\section{PO FIT AND EMPLOYER BRAND CLARITY}

Table 3. Cross-classified multilevel regression analyses predicting employer attractiveness

\begin{tabular}{|c|c|c|c|c|}
\hline \multirow[t]{2}{*}{ Variables } & Null-model & Model 2 & Model 3 & Total model \\
\hline & $\gamma(S E)$ & $\gamma(S E)$ & $\gamma(S E)$ & $\gamma(S E)$ \\
\hline \multicolumn{5}{|l|}{ Individual-per-organization (level 1) } \\
\hline Person-organization fit & & & $0.29(0.00)^{* *}$ & $0.45(0.03)^{* *}$ \\
\hline \multicolumn{5}{|l|}{ Organizational level (level 2) } \\
\hline Employer brand clarity & & & & $0.38(0.09)^{* *}$ \\
\hline Sample size clarity & & $0.00(0.00)^{*}$ & $0.00(0.00)$ & $0.00(0.00)$ \\
\hline Financially healthy & & $0.17(0.11)$ & $0.10(0.11)$ & $0.09(0.10)$ \\
\hline Good training & & $-0.39(0.13)^{* *}$ & $-0.37(0.12)^{* *}$ & $-0.36(0.12)^{* *}$ \\
\hline Long-term job security & & $0.02(0.11)$ & $-0.07(0.10)$ & $-0.04(0.10)$ \\
\hline Career progression opportunities & & $-0.09(0.15)$ & $-0.15(0.15)$ & $-0.17(0.15)$ \\
\hline Strong management & & $0.07(0.13)$ & $0.05(0.12)$ & $0.09(0.12)$ \\
\hline Interesting job content & & $1.14(0.15)^{* *}$ & $0.96(0.14)^{* *}$ & $0.98(0.14)^{* *}$ \\
\hline Pleasant working atmosphere & & $0.26(0.12) *$ & $0.27(0.12)^{*}$ & $0.22(0.12)$ \\
\hline Competitive salary and benefits & & $-0.11(0.14)$ & $-0.21(0.13)$ & $-0.25(0.13)$ \\
\hline Good work-life balance & & $-0.13(0.10)$ & $-0.07(0.10)$ & $-0.08(0.09)$ \\
\hline Environmentally and socially aware & & $0.07(0.07)$ & $0.08(0.07)$ & $0.05(0.07)$ \\
\hline \multicolumn{5}{|l|}{ Individual level } \\
\hline Age & & $0.00(0.00)$ & $0.00(0.00)$ & $0.00(0.00)$ \\
\hline \multicolumn{5}{|l|}{ Cross-level interaction } \\
\hline PO fit*Employer brand clarity & & & & $-0.14(0.03)^{* *}$ \\
\hline \multicolumn{5}{|l|}{ Variance components } \\
\hline Individual-per-organization (level 1) & 0.86 & 0.87 & 0.74 & 0.74 \\
\hline Organizational (level 2) & 0.09 & 0.01 & 0.01 & 0.01 \\
\hline Individual (level 2) & 0.49 & 0.49 & 0.33 & 0.33 \\
\hline Model fit (- 2 Log likelihood) & 70055.00 & 69725.80 & 65501.60 & 65459.60 \\
\hline
\end{tabular}




\section{PO FIT AND EMPLOYER BRAND CLARITY}

Table 4. Replication over years: total model predicting employer attractiveness

\begin{tabular}{|c|c|c|c|}
\hline Variables & $\begin{array}{c}\mathbf{2 0 1 3}^{\mathbf{1}} \\
\text { Total model } \\
\gamma(S E)\end{array}$ & $\begin{array}{c}\mathbf{2 0 1 5}^{\mathbf{2}} \\
\text { Total model } \\
\gamma(S E)\end{array}$ & $\begin{array}{c}\mathbf{2 0 1 7}^{\mathbf{3}} \\
\text { Total model } \\
\gamma(S E)\end{array}$ \\
\hline \multicolumn{4}{|l|}{ Individual-per-organization (level 1) } \\
\hline $\begin{array}{l}\text { Person-organization fit } \\
\text { Organizational level (level 2) }\end{array}$ & $0.51(0.03)^{* *}$ & $0.45(0.03) * *$ & $0.51(0.03) * *$ \\
\hline Employer brand clarity & $0.55(0.09)^{* *}$ & $0.38(0.09)^{* *}$ & $0.31(0.10)^{* *}$ \\
\hline Sample size clarity & $0.00(0.00)^{*}$ & $0.00(0.00)$ & $0.00(0.00)^{* *}$ \\
\hline Financially healthy & $-0.02(0.08)$ & $0.09(0.10)$ & $-0.10(0.06)$ \\
\hline Good training & $-0.47(0.07)^{* *}$ & $-0.36(0.12)^{* *}$ & n.a. \\
\hline Long-term job security & $0.00(0.06)$ & $-0.04(0.10)$ & $-0.12(0.07)$ \\
\hline Career progression opportunities & $-0.09(0.11)$ & $-0.17(0.15)$ & $-0.07(0.09)$ \\
\hline Strong management & $0.07(0.09)$ & $0.09(0.12)$ & n.a. \\
\hline Interesting job content & $0.60(0.08)^{* *}$ & $0.98(0.14)^{* *}$ & $0.48(0.09)^{* *}$ \\
\hline Pleasant working atmosphere & $0.31(0.08)^{* *}$ & $0.22(0.12)$ & $0.30(0.11)^{* *}$ \\
\hline Competitive salary and benefits & $0.18(0.07)^{* *}$ & $-0.25(0.13)$ & $-0.15(0.08)$ \\
\hline Good work-life balance & $-0.12(0.06)^{*}$ & $-0.08(0.09)$ & $-0.05(0.08)$ \\
\hline Environmentally and socially aware & $-0.01(0.04)$ & $0.05(0.07)$ & $-0.08(0.06)$ \\
\hline Newest technologies & n.a. & n.a. & $-0.06(0.07)$ \\
\hline Good reputation & n.a. & n.a. & $0.27(0.08)^{* *}$ \\
\hline \multicolumn{4}{|l|}{ Individual level } \\
\hline Age & $0.00(0.00)$ & $0.00(0.00)$ & n.a. \\
\hline \multicolumn{4}{|l|}{ Cross-level interaction } \\
\hline $\begin{array}{l}\text { PO fit*Employer brand clarity } \\
\text { Variance components }\end{array}$ & $-0.20(0.03)^{* *}$ & $-0.14(0.03)^{* *}$ & $-0.16(0.03)^{* *}$ \\
\hline Individual-per-organization (level 1) & 0.74 & 0.74 & 0.73 \\
\hline Organizational (level 2) & 0.01 & 0.01 & 0.01 \\
\hline Individual (level 2) & 0.30 & 0.33 & 0.29 \\
\hline Model fit (- 2 Log likelihood) & 83107.80 & 65459.60 & 31124.00 \\
\hline
\end{tabular}


Appendix A: Calculation of person-organization fit

Table 5. Coding example PO fit

\begin{tabular}{l|cc|cc|c}
\hline & \multicolumn{2}{|c|}{$\begin{array}{c}\text { Personal } \\
\text { preferences }\end{array}$} & \multicolumn{2}{c|}{$\begin{array}{c}\text { Organizational } \\
\text { score }\end{array}$} & $\begin{array}{c}\text { PO fit } \\
\text { score }\end{array}$ \\
\hline & Original & Recoded & Original & Recoded & \\
\hline Financially healthy & 0 & $\mathbf{0}$ & 2 & $\mathbf{0}$ & 0 \\
Good training & 0 & $\mathbf{0}$ & 3 & $\mathbf{0}$ & 0 \\
Long-term job security & 1 & $\mathbf{1}$ & 3 & $\mathbf{0}$ & 0 \\
Career progression opportunities & 2 & $\mathbf{1}$ & 4 & $\mathbf{1}$ & 1 \\
Strong management & 0 & $\mathbf{0}$ & 5 & $\mathbf{1}$ & 0 \\
Interesting job content & 5 & $\mathbf{1}$ & 2 & $\mathbf{0}$ & 0 \\
Pleasant working atmosphere & 3 & $\mathbf{1}$ & 4 & $\mathbf{1}$ & 1 \\
Competitive salary and employee & 4 & $\mathbf{1}$ & 5 & $\mathbf{1}$ & 1 \\
benefits & 0 & $\mathbf{0}$ & 3 & $\mathbf{0}$ & 0 \\
Good work-life balance & 0 & $\mathbf{0}$ & 4 & $\mathbf{1}$ & 0 \\
Environmentally and socially & -- & -- & -- & $\mathbf{3}$ \\
aware & \multicolumn{7}{|l}{}
\end{tabular}

